The Brock Review Volume 12 No. 1 (2011)

(C) Brock University

\title{
Interview with Jack Hallam
}

John Sorenson

In 2010, Dr. Jack Hallam, an octogenarian currently living on Salt Spring Island, generously endowed Brock University's Department of Sociology with the $\$ 50,000$ Jack Hallam Animal Rights Award, which will provide two scholarships for students registered in Critical Animal Studies. Dr. Hallam also contributed towards the "Thinking About Animals" conference which was held at Brock University on March 31 and April 1, 2011. This conference was organized in collaboration with the Institute for Critical Animal Studies and Brock is especially proud to celebrate this as the tenth annual ICAS conference. John Sorenson talked with Dr. Hallam about the award and his commitment to animal rights and other social justice issues.

John Sorenson: What made you decide to endow a scholarship in animal rights? As well as endowing an animal rights award at Brock University, you've also given endowments to other institutions for students who work on anti-racism and on sexual diversity. Could you talk a bit about your commitment to these various social justice issues and how you see the relationships between them?

Jack Hallam: I'm not sure why or how but I've always had sympathy for underdogs, for minorities and for those whose views were often at odds with the prevailing ethos. This applies to animals as well. Animals, minority races, homosexuals have all been beaten or killed so it is natural that these would be the ones I would try to help in a small way. So having endowed Human Rights awards to counter homophobia and racism at our local high school, entrance bursaries for needy First nations students at Lakehead University and having donated for decades to a number of animal rescue, animal sanctuaries, etc. I thought I would like to endow something at the university level involving studies that would help animals. Thanks to Googling "animal rights courses at Ontario universities" I learned of Lesli Bisgould's course on Animal Rights to law students at Osgoode Hall. From Lesli I learned of your work At Brock so now we have two annual undergraduate Jack Hallam Animal Rights awards. (I feel a little "guilty" putting my name up front but I guess my ego overruled my "guilt.!)...

JS: Could you tell us about how your own animal rights consciousness developed?

JH: I was enormously influenced towards caring for animals by two books that I read in grade 7 and several years later. One, Wild Animals I Have Known, by the Ontario naturalist Ernest Thompson Seaton Had about ten stories with illustrations that some would say are totally anthropomorphic. 
One about a rabbit called Raggylugs and one about a wolf Lobo, king of the Curampaw. Some, or all, were tragic but I read it three or four times. The other was Grey Ow/ written by the Englishman Archie Delaney who passed himself off as an Ojibway ... He took the name grey Owl, married an Ojibway woman and they raised several baby beavers in their house which almost touched a lake, There was a hole in one floor which led to a tunnel that allowed the beavers access to the lake. I found the book enchanting. Sir Charles G.D. Roberts a New Brunswicker wrote animal stories but I don't remember much about them. So, these books [contributed to] my animal rights consciousness.

I was always disposed towards the well being of animals so I regret some things we did in the second year physiology lab. In my Ph.D. research I put many trout and salmon fry and fingerlings directly into bottles of formalin to preserve them. This burned their gills and they died in agony. Fortunately it only took 10 seconds. If I was doing that today $\mathrm{i}$ would first put them into a solution of MS222 a fish anaesthetic which in the 60s was quite expensive. The pet shop I owned for two years I would never do again, mostly tropical fish but we did have reptiles, guinea pigs, gerbils, etc.

Although I've donated to animal rescue organizations for decades, it is only in the last 25 or 30 years that I've taken a position opposing hunting, trapping (cruel leg hold traps), circuses, rodeos zoos etc. Two of my gay friends went to the Gay Rodeo in Calgary a week before the stampede. It is almost as cruel (no chuck wagon races though) except in the calf roping. They told me there is a deliberate weak spot in the rope which lets a struggling calf to break the rope and run away.

I don't think I ever donated to Ducks Unlimited, stopped donating to WWF when they refused to condemn the hunting of wolves in the arctic on snowmobiles. I also stopped donating to the Nature Conservancy (which does do a lot of good work) when they wrote they could not condemn hunting (they [fear they] would lose many donors if they

did).

Since about 1975 I've become a much stronger advocate for animal rights. I'm too soft hearted. I can't bear to watch any cruelty to animals on TV. I oppose hunting and trapping but I reluctantly accept it for First Nations and Inuit in remote regions.

There are many organizations that help animals in some way, most I still support but some no longer. One, PETA is a question mark. Other groups I've supported include WSPA. Zoocheck, the Federation of Humane Societies, Vancouver Humane Society, Island Wildlife Care Centre (one of two in Canada authorized to rescue orphaned seal pups), Donkey Sanctuary, IFAW, Sea Shepherd, the BC SPCA, Animal Alliance and the Environment Voters Party (Norman Taylor).

JS: Who have been the important animals in your own life?

JH: Although my mother was afraid of dogs I received my first pet for my fifth birthday (I must have pestered my parents for one). Probably from a puppy mill he cost $\$ 5$ at the St. Lawrence market. My black and white mongrel, Jip, was very dear to me for 15 years. I collected other animals, some I regret such as the Saw Whet owl who lived in my bedroom for many months. I was upset when I fired a BB gun into a flock of songbirds in a tree and one fell to the ground with beak shattered. I gave that gun away soon after but regret that I gave it to an uncle who used it to keep cats off his flower beds. In Haliburton at my grandmother's cottage on Mountain lake near Minden I had what I considered my own private gravel pit full of water, rushes, cattails, aquatic beetles, dragonfly nymphs etc. and dozens of frogs. One day I arrived to find about 10 dead frogs floating 
belly-up some with more than one BB hole. I was devastated; I was probably about 10 and couldn't then or now understand how someone could do this.

We often went fishing for bass. Told "don't be squeamish" I remember putting a hook through the lips of a small live frog, yes it sometimes caught a legal sized bass (10") but I have not fished for over 50 years. I remember feeling badly when I hit Jip too severely for proudly presenting me with a baby rabbit he had caught. When I was teaching at the Ontario Science Centre I raised two tiny raccoons (a third wouldn't suck from the nipple on a doll's milk bottle). When the two were about 15 pounds I released them up near Lake Simcoe. They imprinted on me. If I walked in a circle they would follow the same path. I've had quite a few cats. I found Puddy (Patte a choux- he had extra toes), crouched in the doorway of Ogilvie's Department store on busy St. Catherine St. in Montreal. He lived to be almost 19. On Salt Spring at one time I had 11 cats, nine of my own (all related, lots of incest) and two a tenant left behind. I could go on about my two donkeys Katy and Peter who became four with Marci (I was midwife) and Gemi. I had Franny and Zoey, pot-bellied pigs. Zoey and two other siblings all died of heart attacks.

My first dog Jip, probably part Border Collie (black and white). size of a cocker spaniel but short hair. I was the only one who fed him, my older sister had no interest in pets. My last dog Blaze, the Love of my Life, Lab/Great Dane cross, Black with a white "blaze" on her chest. Large 120 - 130 lbs, incredibly affectionate and intelligent. Loved to ride in the van, because she was so tall our eyes were at the same level. Tall and let Bart [the cat] walk under her and curl his tail around her fore legs. My last cat Bart, pearl grey his mother was purebred lilac point Siamese. His father was his mother's grandson. Snoopy looked 80\% seal point Siamese (had his father and grandfather's white lower legs and paws. So Bart's mother was also his great grandmother. I was very fond of most of my other cats but Bart who ignored me for 15 years (after being treated for ear mites) has become so affectionate, I think he is aware that the end is near for him and I believe he is aware that I may not have much time left. Just in the last week I allow him to be on the bed during the night. Three years after sending my four donkeys to the sanctuary south of Guelph I acquired two more Cindy and Kipper. Kipper was half brother to Peter. Kipper was very special, the only donkey whom I felt understood that $\mathrm{i}$ was fond of him and he reciprocated. I had sent them to the mainland four years ago to two women whom I first met at the sanctuary in Ontario but sadly Kipper developed a lot of abscesses and had to be euthanized.

JS: What sorts of animal rights issues would you hope to see students engaged with?

JH: The ethics of animals (mostly mammals) used in medical experiments. There should be a total ban on using animals to test cosmetics. Weak laws and small penalties for individual acts of cruelty, including neglect. Why does Britain have the strongest laws for protecting animals? I think one or more of the Scandinavian countries have good legislation protecting farm animals. Factory farming, pigs and chickens. e.g. the horrendous cruel and stupid owners of the Alberta pig farm reported last spring: 400 dead, 168 had to be euthanized and remainder just clinging to life. Erica Ritter in her book The Dog by the Cradle, the Serpent Beneath questions the validity of "Free Range" and "Free Run" eggs so labeled in supermarkets. I now go to a farm for mine but this is not possible even in a small town. Before I stopped buying BBQ chicken I asked if our supermarket could not have "Free Run" BBQ ones. I was told they tried it but the price difference scuttled the plan. As for companion animals, I believe Peter Singer is opposed probably because cats are total carnivores and dogs cannot survive on a totally vegan diet: why can we not buy fowl or red meat that has a sticker guaranteeing that the animals were raised and slaughtered humanely? 
Should there be government funds to help private animal rescue, sanctuaries etc? Should feral cats be spayed/neutered and released or should some be euthanized? The whole question of euthanasia (witness the Toronto Humane Society fiasco). I wish there was a list rating the various organizations and those most worthy of support. Zoos, should they be monitored and regulated for spaciousness, cleanliness etc? Should Lucy be sent to an elephant sanctuary in the states? (I say yes). Aquaria, should marine mammals be kept in captivity for the amusement of humans? With modern technology we can experience them in their native habitat. I worked as biologist at the Alcan Pavilon (Montreal Aquarium) at Expo '67. Our first two dolphins were so poorly shipped that they both died. I'm totally opposed to Dolphins, Orcas, Belugas in Marineland and other such animal exploitive institutions. In May 2009 I adopted Kamina an orphan elephant in the David Sheldrake Wildlife Trust near Nairobi Kenya. Could my $\$ 300$ have been better spent on helping other animals? How do we justify spending large amounts of time, effort and money on non human animals when so many humans are living wretched lives? Circuses, Animals used in TV ads, Rodeos, I don't think a total ban is possible but all should have stringent regulations and be closely monitored. Trophy hunting, Seal "harvest." The whole Vegan question. 